\title{
PENGARUH PENERAPAN PENDIDIKAN KARAKTER MELALUI STRATEGI INKUIRI TERBIMBING PADA MATERI LARUTAN ELEKTROLIT DAN NON ELEKTROLIT
}

\author{
Jenny Belviyani ${ }^{1)}$, Lisa Utami ${ }^{2)}$. \\ ${ }^{1}$ Mahasiswa Program Studi Pendidikan Kimia FTK UIN SUSKA RIAU, Indonesia \\ Email belviyani@gmail.com \\ ${ }^{2}$ Dosen Program Studi Pendidikan Kimia FTK UIN SUSKA RIAU, Indonesia \\ Email 1154_lazoelva@yahoo.com
}

\begin{abstract}
This research was a quasi-experiment instigated by the low of student character building. This research aimed at knowing the effect of implementing character building through guided inquiry strategy on electrolyte and non-electrolyte solution material at state senior high school 9 pekanbaru that characters studied were honesty, responsibility, cooperation, discipline, and curiosity. Purposive sampling was used in this research, and there were two classes of samples selected that the tenth grade of Natural Science 4 was as the experimental group taught by implementing Character Building through Guided Inquiry strategy and Natural Science 3 was as the control group taught by using discussion, question and answer methods. This research was conducted for three meetings. Documentation and observation were the techniques of collecting the data. T-test was used to know the research findings of student communication skill. Final data processing results showed that $t_{\text {observed }}$ was 2.19 and $t_{\text {table }}$ was 1.99 , and it revealed that $t_{\text {observed }}$ was higher than $t_{\text {table. }} H_{o}$ was rejected and $H_{a}$ was accepted. There was an effect of implementing Character Building through Guided Inquiry strategy on Electrolyte and Non-Electrolyte Solution material at State Senior High School 9 Pekanbaru, and its coefficient effect was 5.86\%.
\end{abstract}

Keywords: Character building, Guided inquiry strategy, Electrolyte and non electrolyte solution material.

\section{PENDAHULUAN}

Pendidikan karakter menjadi salah satu hal yang sangat penting dalam dunia pendidikan. Sesuai dengan UU No. 20 Tahun 2003 Tentang Sistem Pendidikan Nasional pada pasal 3, yang menyebutkan bahwa pendidikan nasional berfungsi mengembangkan kemampuan dan membentuk karakter serta peradaban bangsa yang bermartabat dalam rangka mencerdaskan kehidupan bangsa. Pendidikan nasional bertujuan untuk berkembangnya potensi peserta didik agar menjadi manusia yang beriman dan bertakwa kepada Tuhan Yang Maha Esa, berakhlak mulia, sehat, berilmu, cakap, kreatif, mandiri, dan menjadi warga negara yang demokratis serta bertanggung jawab (Fitria, 2012). Dari fungsi dan tujuan tersebut diketahui bahwa siswa di sekolah tidak hanya memperoleh pengetahuan dan kemampuan kognitif saja, namun juga harus diimbangi dengan pembentukan karakter yang baik.

Pendidikan karakter adalah pendidikan untuk membentuk kepribadian seseorang melalui pendidikan budi pekerti, yang hasilnya terlibat dalam tindakan nyata seseorang, yaitu tingkah laku yang baik, jujur dan bertanggung jawab, menghormati hak orang lain, kerja keras dan sebagainya. Pendidikan karakter pada intinya bertujuan membentuk bangsa yang tangguh, kompetitif, berakhlak mulia, bermoral, bertoleran, bergotong royong, berjiwa politik, berkembang dinamis, berorientasi ilmu pengetahuan dan teknologi yang semuanya dijiwai oleh iman dan takwa kepada Tuhan Yang Maha Esa (Gunawan, 2014). Pembangunan karakter adalah usaha paling penting yang pernah diberikan kepada manusia. Pembangunan karakter adalah tujuan luar biasa dari sistem pendidikan yang benar. Pendidikan karakter mengajarkan kebiasaan cara berpikir dan perilaku yang membantu individu untuk hidup dan bekerja sama sebagai keluarga, masyarakat, dan bernegara dan membantu mereka untuk membuat keputusan yang dapat dipertanggungjawabkan (Lepiyanto, 2012).

Indonesia memerlukan peningkatan pendidikan karakter dalam dunia pendidikan. 
Hal ini disebabkan banyak kasus yang terjadi pada saat ini yang melibatkan siswa, seperti perkelahian secara masal (tawuran antar pelajar), pemerkosaan, perlakuan seks yang berlebihan, pencurian atau bahkan pembunuhan antar pelajar. Kasus ini terlihat sangat mencoreng bangsa Indonesia terutama dunia pendidikan. Untuk membantu memperbaiki karakter siswa diperlukan kerja sama antara lingkungan sekolah, lingkungan sosial serta orang tua secara bertahap.

Didalam Al-Quran juga telah di jelaskan tentang konsep pendidikan karakter yang tertera dalam Surah Luqman Ayat 12-14 :

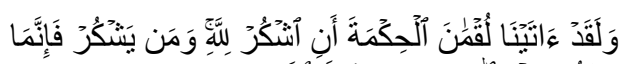

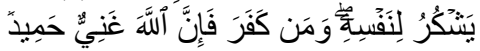

Artinya: "dan sesungguhnya telah Kami berikan hikmat kepada Luqman, yaitu: "Bersyukurlah kepada Allah. Dan barang siapa yg bersyukur (kepada Allah), maka sesungguhnya ia bersyukur untuk dirinya sendiri; dan barang siapa yang tidak bersyukur, maka sesungguhnya Allah Maha Kaya lagi Maha Terpuji."

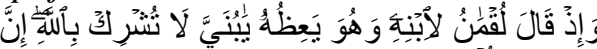

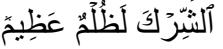

Artinya: "dan (ingatlah) ketika Luqman berkata kepada anaknya, diwaktu ia memberi pelajaran kepadanya: "Hai anakku, janganlah kaтu mempersekutukan Allah, sesungguhnya mempersekutukan (Allah) adalah benar-benar kezaliman yang besar."

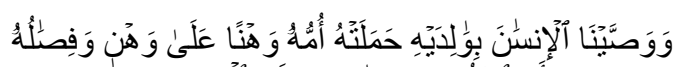

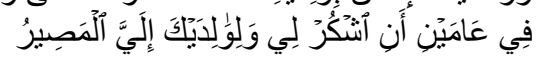

Artinya: "dan Kami perintahkan kepada manusia (berbuat baik) kepada dua orang ibubapanya; ibunya telah mengandungnya dalam keadaan lemah yang bertambah-tambah, dan menyapihnya dalam dua tahun 1180. Bersyukurlah kepadaKu dan kepada dua orang ibu bapakmu, hanya kepada-Kulah kembalimu" (Depag, 2007).

Dari ayat di atas dapat diketahui bahwa konsep pendidikan karakter dalam Al-Qur'an surat Luqman ayat 12-14 adalah penekanan terhadap pentingnya implementasi dari konsep hikmah, yaitu keselarasan atau kesesuaian antara ilmu dan amal, manusia pada dasarnya diperintahkan untuk senantiasa bersyukur kepada Allah SWT.

Berdasarkan hasil wawancara dengan guru kimia kelas $\mathrm{X}$ didapatkan bahwa dalam pokok bahasan larutan elektrolit dan non elektrolit guru sudah menerapkan metode diskusi dan praktikum, dimana sebagian proses diskusi yang diterapkan adalah proses diskusi dalam kelompok besar, sehingga siswa yang bekerja dalam kelompok tidak maksimal. Namun sebagian besar nilai yang diperoleh siswa pada materi larutan elektrolit dan non elektrolit sudah memenuhi KKM yaitu 78 . Ketuntasan tersebut belum sejalan dengan sikap sosial dan karakter yang harus diterapkan dengan baik. Hal ini menunjukkan bahwa nilai yang telah memenuhi KKM bukan dari hasil pemahaman diri siswa sendiri dan nilai karakter siswa belum tampak pada proses pembelajaran. Melalui materi larutan elektolit dan non elektrolit, nilai karakter jujur, kerja sama, tanggung jawab, disiplin, dan rasa ingin tahu dapat terlihat jelas. Seperti dalam mengerjakan praktikum, nilai karakter jujur dapat dilihat apakah laporan praktikum yang dibuat sesuai dengan hasil praktikum, nilai karakter tanggung jawab dapat dilihat apakah siswa dapat bertanggung jawab dengan alat laboratorium yang digunakan, nilai karakter kerja sama dapat dilihat dalam kerja kelompok, nilai karakter disiplin dapat dilihat apakah siswa masuk kelas tepat waktu dan kegiatan di dalam kelas, dan nilai karakter rasa ingin tahu dapat dilihat selama proses pembelajaran di dalam kelas dan di dalam laboratorium.

Pada proses pembelajaran diperlukan suatu strategi yang tepat untuk materi yang disajikan. Salah satu strategi yang dapat digunakan adalah strategi inkuiri terbimbing (guided inquiry). Inkuiri tingkat pertama ini merupakan inkuiri dimana masalah dikemukakan oleh guru atau bersumber dari buku teks kemudian siswa bekerja untuk menemukan jawaban terhadap masalah dengan bimbingan intensif yang diberikan oleh guru. Dengan demikian, guru yang mengelola kegiatan belajar dengan baik. Inkuiri ini cocok untuk diterapkan dalam pembelajaran mengenai konsep-konsep dan prinsip-prinsip yang mendasar dalam bidang tertentu.

Pada strategi ini siswa dihadapkan pada tugas-tugas yang relevan untuk diselesaikan dengan baik melalui diskusi kelompok maupun secara individual agar mampu menyelesaikan masalah dan menarik suatu kesimpulan secara mandiri. Pada dasarnya siswa selama proses belajar berlangsung akan memperoleh pedoman sesuai dengan yang diperlukan. Pada tahap awal guru banyak memberikan bimbingan, kemudian pada tahap berikutnya, bimbingan tersebut 
dikurangi, sehingga siswa mampu melakukan proses inkuiri secara mandiri. Bimbingan yang diberikan dapat berupa pertanyaan-pertanyaan dan diskusi multi arah yang dapat mengiring siswa agar dapat memahami konsep pelajaran. Disamping itu. bimbingan dapat pula diberikan melalui lembar kerja yang terstruktur. Selama berlangsungnya proses belajar, guru harus memantau kelompok diskusi siswa, sehingga guru dapat mengetahui dan memberikan petunjuk-petunjuk yang diperlukan siswa (Suyadi, 2013).

Jika pada pokok bahasan larutan elektrolit dan non elektrolit diberikan strategi inkuri terbimbing yang menerapkan pendidikan karakter dalam setiap langkah pembelajarannya, diharapkan siswa akan dapat langsung mengamati larutan yang dapat menghantarkan arus listrik dan mana yang tidak, serta dapat mengkaitkannya dengan kehidupan sehari-hari. Ini didukung oleh penelitian sebelumnya yang menyimpulkan bahwa terdapat perbedaan yang signifikan antara pertemuan pertama, kedua, dan pertemuan ketiga serta terdapat peningkatan pencapaian secara rerata hasil afektif peserta didik dalam setiap pertemuan. Selain itu, frekuensi pencapaian afektif terbanyak peserta didik, berada pada pencapaian (kategori) "Mulai Berkembang". Hal ini dikarena kegiatan pembelajaran dengan pendekatan inkuiri terbimbing, mampu menghasilkan peningkatan pada sikap ilmiah (afektif) peserta didik. Beberapa hal yang mempengaruhi pencapaian tersebut adalah guru yang tidak menggunakan metode indoktrinasi, tapi inkulkasi (pe nanaman). Selain itu, nilai-nilai tersebut tidaklah diajarkan, tetapi dikembangkan. Selain metode inkulkasi dan pengembangan nilai, guru juga memberikan teladan yang baik sebagai metode tambahan untuk mendidik karakter peserta didik (Asyaharil, 2010).

Berdasarkan materi larutan elektrolit dan non elektrolit dan strategi inkuiri terbimbing yang akan digunakan, maka karakter yang diterapkan dalam pembelajaran adalah jujur, tanggung jawab, rasa ingin tahu, disiplin, dan bekerja sama. Penerapan pendidikan karakter pada pembelajaran larutan elektrolit dan non elektrolit menggunakan inkuiri terbimbing diharapkan memberikan pengaruh pada nilai karakter siswa menjadi lebih baik.

\section{METODE PENELITIAN}

Penelitian dilaksanakan di SMA Negeri 9 Pekanbaru pada kelas X semester 2 pada bulan april- mei tahun pelajaran 2017/2018. Penelitian yang dilakukan merupakan penelitian kualitatif menggunakan metode eksperimen semu (quasy experimental research). Populasi dalam penelitian adalah seluruh kelas X SMA Negeri 9 Pekanbaru tahun pelajaran 2017/2018. Teknik pengambilan sampel dengan Purposive Sampling yaitu teknik sampling yang digunakan peneliti jika peneliti mempunyai pertimbanganpertimbangan atau tujuan tertentu. Sampel yang terpilih adalah kelas X IPA 4 sebagai kelas eksperimen dan X IPA 3 sebagai kelas kontrol. Masing-masing kelas terdiri dari 40 dan 39 siswa.

Variabel bebas yang digunakan masingmasing adalah penerapan pendidikan karakter melalui strategi pembelajaran inkuiri terbibimbing yang diterapkan pada kelas eksperimen dan model pembelajaran konvensional yang diterapkan pada kelas kontrol. Variabel terikat dalam penelitian adalah pendidikan karakter yang meliputi nilai karakter jujur, tanggung jawab, kerja sama, disiplin, dan rasa ingin tahu. Teknik pengumpulan data menggunakan lembar observasi dan dokumentasi. Lembar observasi digunakan untuk mengukur nilai karakter siswa, sedangkan dokumentasi digunakan untuk mendokumentasikan aktivitas siswa saat pembelajaran berlangsung.

Analisa data penelitian, terdiri atas validitas empiris menggunakan rumus Korelasi Pearson Product Moment, reliabilitas non tes menggunakan rumus Cronbach Alpha ( $\alpha$ ), analisis nilai rata-rata karakter siswa menggunakan rumus: nilai rata-rata

$$
\frac{\text { Jumian gwor senunh siswa }}{\text { fumiah siswa } x \text { Baryaknyo indikator } x \text { shor maksimal }} \times 4
$$

Adapun kriteria interpretasi penilaian karakter siswa yang disesuaikan dengan Kemendiknas disajikan dalam Tabel 1.

Tabel 1. Interpretasi Batasan Nilai Karakter

\begin{tabular}{|c|c|}
\hline Batasan & Kriteria \\
\hline $1,00-1,99$ & Belum Terlihat (BT) \\
\hline $2,00-2,99$ & Mulai Terlihat (MT) \\
\hline $3,00-3,49$ & Mulai Berkembang (MB) \\
\hline $3,50-4,00$ & Membudaya (MK) \\
\hline
\end{tabular}

(Arikunto, 2009)

Siswa dikatakan telah melatihkan karakter yang diharapkan apabila pada lembar pengamatan karakter siswa memperoleh nilai 
rata-rata pada kriteria mulai berkembang atau membudaya $(\geq 3,00)$.

Sebelum menganalisis data dengan test" $t$ ", maka data yang didapat harus dilakukan uji normalitas terlebih dahulu, uji ini bertujuan untuk menguji apakah suatu sampel dalam penelitian ini berasal dari populasi yang normal atau tidak. Untuk menguji normalitasnya dapat menggunakan Chi kuadrat.

\section{HASIL DAN PEMBAHASAN}

\section{Hasil Penelitian}

Data hasil penelitian ini adalah nilai karakter siswa pada materi larutan elektrolit dan non elektrolit. Pengukuran nilai karakter siswa menggunakan lembar observasi. Data hasil penelitian tersebut diperoleh dari dua kelas sampel yang merupakan bagian dari populasi kelas X SMA Negeri 9 Pekanbaru. Kelas X IPA 4 sebagai kelas eksperimen yang terdiri dari 40 siswa dan kelas X IPA 3 sebagai kelas kontrol yang terdiri dari 39 siswa. Kelas kontrol menggunakan pembelajaran konvensional yaitu diskusi dan tanya jawab sedangkan kelas eksperimen menggunakan strategi inkuiri terbimbing.

Data hasil penelitian berupa nilai karakter siswa diukur menggunakan lembar observasi saat pembelajaran berlangsung. Nilai observasi karakter siswa antara kelompok kontrol dan kelompok eksperimen dianalisis dengan uji parametrik yaitu uji t. Uji t digunakan untuk mengetahui ada tidaknya perbedaan signifikan antara nilai kelompok kontrol dengan kelompok eksperimen, namun sebelum dilakukan uji $\mathrm{t}$ harus dilakukan uji normalitas. Berdasarkan analisis tersebut dapat diketahui ada tidaknya pengaruh strategi inkuiri terbimbing terhadap nilai karakter siswa. Rancangan hipotesis untuk keputusan uji adalah

$\mathrm{H}_{0}$ : Tidak ada Pengaruh Penerapan Pendidikan Karakter melaui strategi Inkuiri Terbimbing pada materi Larutan Elektrolit dan Non Elektrolit di kelas X IPA SMAN 9 Pekanbaru.

$\mathrm{H}_{\mathrm{a}}$ : Ada Pengaruh Penerapan Pendidikan Karakter melaui model Inkuiri Ter bimbing pada materi Larutan Elektrolit dan Non elektrolit di kelas X IPA SMAN 9 Pekanbaru.

Hasil uji t yang disajikan dalam Tabel 2.

Tabel 2. Hasil Analisis Data Uji Hipotesis Indikator Pendidikan Karakter Siswa

\begin{tabular}{|c|l|l|c|l|l|}
\hline Kelas & $\mathbf{N}$ & $\sum \mathbf{X}$ & $\overline{\boldsymbol{X}}$ & $\mathbf{t}_{\text {hitung }}$ & $\mathbf{t}_{\text {tabel }}$ \\
\hline Eksperimen & 40 & 2382 & 59,56 & 2,99 & 1,99 \\
\hline Kontrol & 39 & 2271 & 58 & & \\
\hline
\end{tabular}

Berdasarkan Tabel 2 dapat dilihat nilai $t_{\text {hitung }}>t_{\text {tabel }}$, maka hipotesis "terdapat pengaruh penerapan pendidikan karakter melalui strategi inkuiri terbimbing masalah pendidikan karakter siswa" diterima.

Setelah diketahui adanya pengaruh penerapan pendidikan karakter melalui strategi inkuiri terbimbing yang dianalisis menggunakan uji t. maka dapat diketahui juga derajat peningkatan pendidikan karakter siswa yang dilakukan dengan menghitung koefisien korelasi $\left(\mathrm{r}^{2}\right)$ sedangkan peningkatan koefisien pengaruh (KP) dapat menggunakan $r^{2} \times 100 \%$. Hasil perhitungan koefisien pengaruh yang disajikan dalam Tabel 3.

\begin{tabular}{c|c}
\multicolumn{2}{c}{ Tabel 3. Uji $\mathbf{r}^{2}$ dan KP } \\
\hline $\mathbf{r}^{\mathbf{2}}$ & $\mathbf{K P}$ \\
\hline 0,0586 & $5,86 \%$ \\
\hline
\end{tabular}

Berdasarkan Tabel 3 dapat disimpulkan bahwa besar pengaruh penerapan pendidikan karakter melalui strategi inkuiri terbimbing pada materi larutan elektrolit dan non elektrolit di Sekolah Menengah Atas Negeri 9 Pekanbaru adalah $5,86 \%$.

\section{PEMBAHASAN}

Pengamatan karakter siswa oleh pengamat bertujuan untuk mengetahui nilai karakter siswa yang telah diterapkan dengan strategi inkuiri terbimbing. Data pengamatan karakter siswa dilakukan oleh pengamat sebanyak 3 orang. Penilaian dilakukan pada setiap akhir pembelajaran selama 3 kali pertemuan. Data hasil pengamatan karakter jujur siswa disajikan dalam Gambar 1.

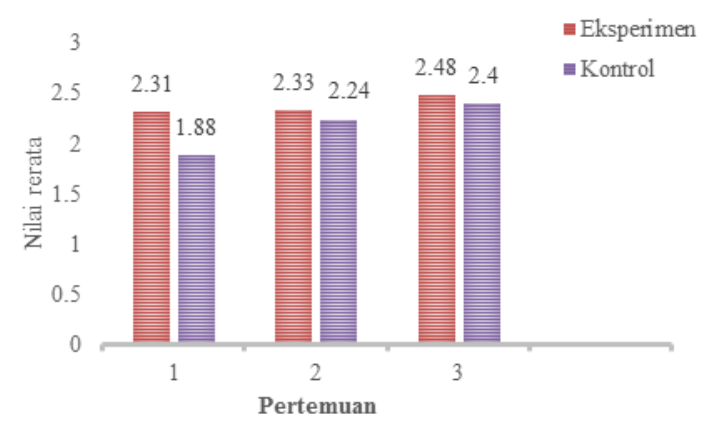

Gambar 1. Hasil Penilaian Karakter Jujur Kelas Sampel.

Berdasarkan Gambar 1, dapat diketahui bahwa dalam tiga kali pertemuan kelas 
eksperimen memiliki rata-rata yang lebih tinggi dibandingkan dengan kelas kontrol. Pada kelas eksperimen terjadi peningkatan nilai karakter sikap jujur, yang mana didalam tiga pertemuan tersebut termasuk ke dalam kriteria nilai karakter mulai terlihat. Hal ini menunjukkan bahwa selama tiga kali pertemuan siswa mulai dapat melatihkan karakter jujur secara bertahap.

Selanjutnya nilai karakter jujur di kelas kontrol memiliki nilai rata-rata lebih rendah yang mana pada pertemuan pertama nilai karakter siswa termasuk dalam kategori belum terlihat dan pada pertemuan kedua dan ketiga termasuk ke dalam kategori mulai terlihat. Siswa dikatakan termasuk dalam kategori belum terlihat apabila siswa belum memperlihatkan tanda-tanda awal perilaku atau karakter yang dinyatakan dalam indikator. Selanjutnya, siswa dikatakan termasuk dalam kategori mulai terlihat apabila siswa sudah mulai memperlihatkan adanya tanda-tanda awal perilaku atau karakter yang dinyatakan dalam indikator tetapi belum konsisten.

Pada strategi inkuiri terbimbing yang menerapkan pendidikan karakter jujur di dalam langkah pembelajaran ini guru selalau membimbing siswa dalam setiap kegiatan pembelajaran. Sehingga, di dalam kegiatan pembelajaran siswa selalu dibimbing untuk selalu bersikap jujur dalam mengerjakan ulangan ataupun membuat laporan, tidak memplagiat setiap tugas yang berikan dan selalu bertindak jujur dalam kehidupan sehari-hari. Jujur merupakan perilaku yang didasari pada upaya menjadikan dirinya sebagai orang yang selalu dapat dipercaya dalam perkataan, tindakan, dan perkerjaan, baik terhadap diri sendiri dan orang lain. Jujur dapat dilihat dari perilaku yang mampu menyatakan apa adanya, terbuka, dan konsisten antara apa yang dikatakan dan dilakukan, beran karena benar, dapat dipercaya dan tidak curang (Samani, 2012). Dengan melatih sikap jujur pada diri siswa diharapkan dapat membentuk nilai-nilai luhur dan perilaku yang berkarakter.

Data hasil pengamatan karakter tanggung jawab siswa dapat disajikan pada Gambar 2.

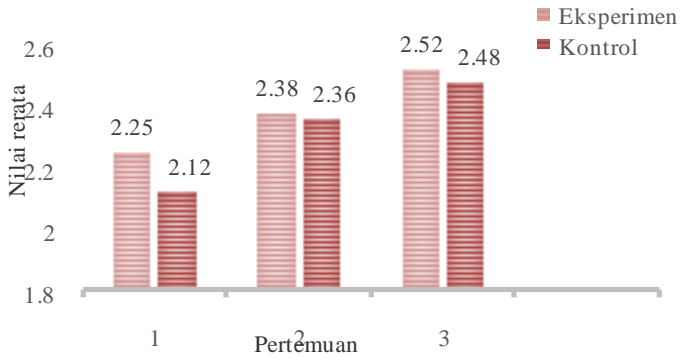

Gambar 2. Hasil Penilaian Karakater Tanggung Jawab Kelas Sampel.

Berdasarkan Gambar 2, dapat diketahui bahwa dalam penilaian karakter tanggung jawab rata-rata kelas eksperimen lebih tinggi dibandingkan dengan kelas kontrol yang mana dalam ketiga pertemuan terdapat peningkatan dan termasuk ke dalam kategori mulai terlihat. Hal ini menunjukkan bahwa selama tiga kali pertemuan, siswa mulai dapat melatih nilai karakter tanggung jawab secara bertahap. Selanjutnya, pada kelas kontrol, nilai karakter tanggung jawab termasuk ke dalam kategori mulai terlihat.

Nilai tanggung jawab yang dimaksud adalah upaya sungguh-sungguh dalam mempertanggung jawabkan setiap tindakan yang dilakukan selama berada di lingkungan sekolah, seperti melaksanakan tugas yang diberikan dengan baik, menerima resiko atas tindakan yang dilakukan, mengembalikan barang yang dipinjam. Pada strategi inkuiri terbimbing yang menerapkan nilai karakter tanggung jawab di dalam setiap langkah pembelajarannya guru selalu membimbing siswa dalam setiap kegiatan pembelajaran, yang dimana untuk karakter tanggung jawab guru selalu memotivasi siswa dalam melaksanakan tugas yang dikerjakan dengan jujur dan baik akan mendapatkan nilai tambahan. Dengan demikian, siswa dapat melatih sikap tanggung jawab dalam kegiatan belajar. Berbeda dengan kelas kontrol, dimana siswa tidak di motivasi seperti halnya di kelas eksperimen. Sehingga dalam observasi yang dilakukan, nilai karakter tanggung jawab pada kelas eksperimen lebih tinggi dibandingkan dengan kelas kontrol.

Salah satu indikator tanggung jawab ialah bertanggung jawab atas segala tindakan yang dilakukan. Sependapat dengan penelitian ter dahulu yang menjelaskan bahwa memenuhi kewajiban diri dan dapat dipercaya merupakan indikator dari tanggung jawab (Sukadiyanto, 2011). 
Data hasil pengamatan karakter kerja sama dapat disajikan dalam bentuk diagram pada Gambar 3.

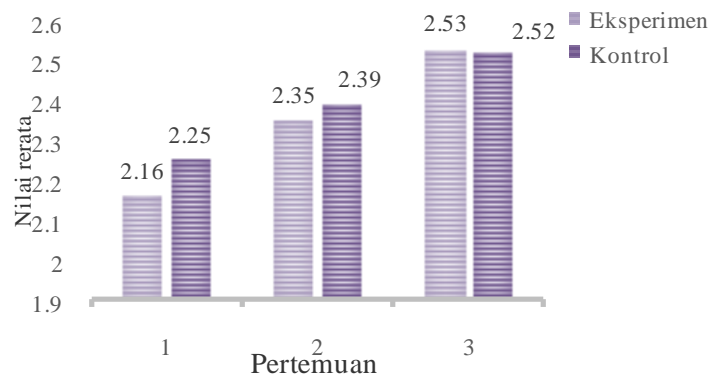

Gambar 3. Hasil Penilaian Karakater Kerja Sama Kelas Sampel.

Berbeda dengan nilai karakter jujur dan tanggung jawab, penilaian karakter kerja sama pada pertemuan pertama dan pertemuan kedua nilai rata-rata kelas kontrol lebih tinggi dibandingkan dengan kelas eksperimen, namun dari kedua kelas nilai karakter kerja sama sudah termasuk dalam kategori mulai terlihat. Hal ini diasumsikan siswa kelas eksperimen dalam melakukan diskusi cenderung bekerja mandiri dikarenakan faktor psikologi dalam diri mereka yang merasa mampu dalam mengerjakan tugas sendiri. Berbeda dengan kelas kontrol yang sangat bersemangat dalam kerja kelompok. Namun, penilaian karakter kerja sama termasuk dalam kategori mulai terlihat, baik di kelas eksperimen ataupun kelas kontrol. Karakter kerja sama dapat ditanamkan, dilatih, dan dikembangkan melalui berbagai cara, salah satu bentuknya melalui kegiatan pembelajaran (Yulianti, 2013).

Data hasil pengamatan karakter disiplin dapat disajikan dalam bentuk diagram pada Gambar 4.

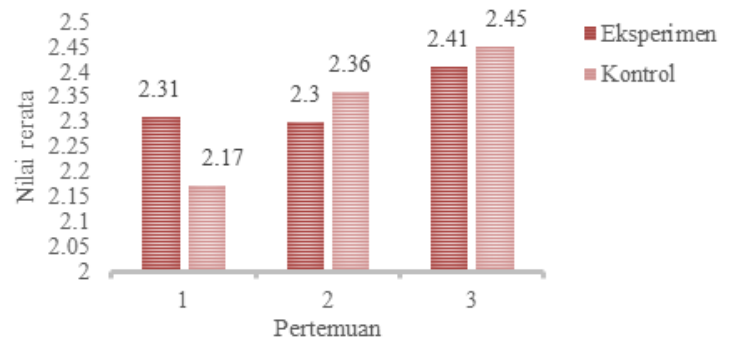

Gambar 4. Hasil Penilaian Karakater Disiplin Kelas Sampel.

Disiplin merupakan suatu perilaku tertib dan patuh pada berbagai ketentuan dan peraturan (Retno, 2012). Dari gambar di atas, dapat dilihat bahwa pada pertemuan pertama hingga pertemuan ketiga, rata-rata nilai karakter disiplin pada kelas eksperimen terjadi penurunan. Penurunan nilai karakter disiplin pada pertemuan kedua diasumsikan karena banyak siswa yang mengikuti kegiatan OSIS, kemudian banyak siswa yang mempersiapkan pagelaran seni yang akan diselenggarakan sesudah jam pelajaran kimia, sehingga banyak siswa yang tidak fokus dalam belajar. Dari kedua kelas, nilai karakter siswa sudah termasuk dalam kategori mulai terlihat.

Data hasil pengamatan karakter rasa ingin tahu dapat disajikan dalam bentuk diagram pada Gambar 5.

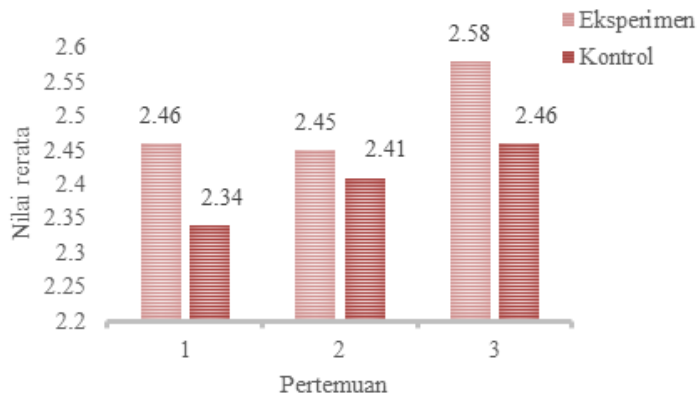

Gambar 5. Hasil Penilaian Karakater Rasa Ingin Tahu Kelas Sampel.

Nilai karakter rasa ingin tahu merupakan sikap dan tindakan yang selalu berupaya untuk mengetahui lebih mendalam dan meluas dari suatu yang dipelajarinya, dilihat, dan didengar (Retno, 2012). Pada Gambar 5, di kelas eksperimen pada pertemuan pertama hingga pertemuan ketiga sudah termasuk dalam kategori mulai terlihat. Pada pertemuan kedua terjadi penurunan nilai karakter rasa ingin tahu yaitu sebesar $1 \%$. Hal ini diasumsikan karena ketidakfokusan siswa dalam mengikuti kegiatan belajar mengajar. Namun, pada pertemuan ketiga terjadi peningkatan nilai karakter rasa ingin tahu sebesar 3\%. Selanjutnya pada kelas kontrol, nilai karakter rasa ingin tahu juga sudah termasuk dalam kategori mulai terlihat, namun sudah terlihat jelas bahwa hasil penilaian karakter rasa ingin tahu kelas kontrol lebih rendah dibandingkan kelas eksperimen.

Dari hasil kelima karakter yang diamati, nilai karakter rasa ingin tahu memiliki rata-rata yang paling tinggi dari pengamatan selama tiga kali pertemuan. Hal ini dapat dilihat dari keaktifan siswa dalam mengikuti proses pembelajaran, sering bertanya tentang materi yang kurang dipahami, dan antusias dalam mengikuti proses pembelajaran. Peningkatan nilai karakter rasa ingin tahu ini diasumsikan 
karena pada strategi inkuiri terbimbing yang dimana guru selalu membimbing siswa dalam kegiatan pembelajaran, sehingga siswa yang tidak paham materi akan dibimbing secara intensif sehingga rasa ingin tahu akan materi pelajaran pada diri siswa mulai tumbuh dan juga siswa yang ingin bermalas-malasanpun berkurang karena adanya bimbingan tersebut. Sejalan pula dengan penelitian terdahulu yang menyatakan bahwa kegiatan pembelajaran dengan pendekatan inkuiri terbimbing mampu menghasilkan peningkatan pada sikap afektif peserta didik. Beberapa hal yang mempengaruhi pencapaian tersebut adalah guru yang tidak menggunakan metode indoktrinasi, tapi inkulkasi (penanaman). Selain itu, nilai-nilai tersebut tidaklah diajarkan, tetapi dikembang kan (Murdilanto, 2010). Sehubungan dengan itu, megungkapkan bahwa secara implisit pembelajaran inkuiri merupakan manifestasi dara "rasa ingin tahu". Sedangkan rasa ingin tahu itu sendiri adalah salah satu nilai karakter yang dirumuskan Kemendikbud. Dengan demikian, secara tidak langsung strategi inkuiri terbimbing telah memuat nilai salah satu nilai karakter (Suyadi, 2013). Hal ini sesuai dengan hasil penelitian bahwa nilai karakter rasa ingin tahu mempunyai nilai rata-rata karakter yang paling tinggi.

Berdasarkan hasil penelitian selama pembelajaran, beberapa nilai karakter mengalami peningkatan yang sangat sedikit, misalnya sikap disiplin. Hal ini dapat terjadi karena berbagia faktor, salah satunya yaitu kurangnya waktu dalam proses pembelajaran untuk menerapkan nilai karakter di dalam langkah-langkah pembelajaran. Dalam menerap kan pendidikan karakter di dalam proses pembelajaran memang membutuhkan waktu yang cukup lama agar penerapan pendidikan karakter ini dapat membentuk sikap siswa sesuai dengan yang di harapkan. Hal ini didukung oleh hasil penelitian terdahulu yang menyebutkan bahwa pembentukan karakter siswa membutuhkan waktu yang lama (Lepiyanto, 2013).

Pendidikan karakter yang baik, seharusnya di mulai dari rumah, karena sekolah hanya membantu peserta didik untuk mengembangkan karakter. Pendidikan karakter yang di mulai dari rumah, akan mencerminkan perilaku peserta didik disekolah, kemudian guru akan membantu untuk mengembangkan dan mendidik karakter dengan menerapkan nilainilai moral, sehingga peserta didik dapat mengidentifikasi bahwa perilaku tersebu tbaik atau tidak baik.

\section{KESIMPULAN}

Dari analisis data yang telah dilakukan, dinyatakan dua hasil dari penelitian ini. Pertama, dengan uji-t yang menunjukkan $t_{\text {hitung }}$ $>\mathrm{t}_{\text {tabel }}$ dengan nilai hitung $2,19>1,99$ yang artinya $\mathrm{Ha}$ diterima dan $\mathrm{H}_{0}$ ditolak. Sehingga penerapan pendidikan karakter melalui strategi inkuiri terbimbing mempengaruhi pendidikan karakter siswa kelas $\mathrm{X}$ pada materi larutan elektrolit dan non elektrolit di SMA Negeri 9 Pekanbaru. Kedua, besarnya pengaruh penerapan pendidikan karakter melalui strategi inkuiri terbimbing pada materi larutan elektrolit dan non elektrolit di kelas X SMA Negeri 9 Pekanbaru adalah sebesar 5,86 \% yang termasuk dalam kategori mulai terlihat.

\section{DAFTAR PUSTAKA}

Agil, Lepiyanto. 2012. Implementasi Lesson Study Pada Matode Number Heads Together Dipadu Dengan Team Games Tournamaent Untuk Pengembangan Karakter Siswa Kelas X SMA Negeri 1 Kepanjen. Bioedukasi, Volume. 3 Nomor. 2.

Asyaharil, A., Risa, H. 2010. Implementasi Pembelajaran Fisika SMA Berbasis Inkuiri Terbimbing Terintegrasi Pendidikan Karakter Untuk Meningkatkan Hasil Belajar Siswa Pada Materi Cahaya Dan Optika.

Departemen Agama RI. 2007. Al-Qur'an dan Terjemahnya. Bandung.

Fitria, I,. Bertha, Y. 2012. Keterampilan Sosial Siswa Pada Materi Larutan Elektrolit Dan Non Elektrolit Di SMA Negeri 1 Surabaya Pada Penerapan Model Pembelajaran Kooperatif Tipe Think Pair Share (TPS). Unesa Journal of Chemichal Education. Volume 1, Nomor 2, hlm. 19-26.

Lepiyanto, A. 2012. Implementasi Lesson Study pada Metode Numbered Heads Together dipadu dengan Team Games Tournament untuk Pengembangan Karakter, Peningkatan Aktivitas, Motivasi, dan Hasil Belajar Biologi Siswa SMA Negeri 1 Kepanjen. Bioedukasi. Volume 3, Nomor 2.

Mundilarto. 2010. Inquiry-Based Learning dan Pengembangan 
Pembelajarannya. Laporan Penelitian Pengembangan Ilmu Guru Besar, Yogyakarta, Penerbit UNY.

Retno, L. 2012. Pendidikan Karakter dalam Metode Aktif, Inovatif, dan Kreatif. Jakarta, Penerbit Erlangga.

Samani, M dan Hariyanto. 2012. Konsep dan Model Pendidikan Karakter. Bandung, Penerbit Remaja Rosdakarya.

Suharsimi Arikunto. 2009. Dasar-dasar Evaluasi Pendidikan. Jakarta, Penerbit Bumi Aksara.

Sukadiyanto. 2011. Implementasi Pendidikan Karakter dalam Pendidikan Jasmani dan
Olahraga Pendidikan Karakter dalam Perspektif Teori dan Praktik. Yogyakarta, Penerbit UNY Press.

Suyadi. 2013. Strategi Pembelajaran Pendidikan Karakter. Bandung, Penerbit PT. Remaja Rosdakarya.

Yulianti, D, S. 2013. Pendidikan Karakter Kerja Sama Dalam Pembelajaran Siswa Sekolah Dasar Pada Kurikulum 2013. Jurnal Teori dan Praksis Pembelajaran IPS. Volume 1, Nomor 1, ISSN: 25031201.

Gunawan, Heri. 2014. Pendidikan Karakter. Bandung, Penerbit Alfabeta. 